\title{
Analisis Aspek Perkembangan Kognitif Dan Motorik Dalam Permainan Jump Count Melalui Abacus Tangga
}

\author{
Ririn Dwi Wiresti \\ UIN Sunan Kalijaga Yogyakarta \\ Email: ririnwiresti@gmail.com
}

Article received: 26 April 2020, Review process: 29 April 2020,

Article Accepted: 25 Oktober 2020, Article published: 30 Maret 2021

\begin{abstract}
Early childhood is a child with an age range of 0 to 6 years who must be given stimulation for their development. Following the regulation of the Minister of Education and culture (Permendikbud) No. 137 of 2014, there are six aspects of child development, namely physical-motor, religious and moral values, language, art, motor, and cognitive. In its application several points of progress can be stimulated simultaneously. For example, in coloring activities, points of development that was stimulated are excellent motor and art. In reality sometimes there is a separation between the practice of cognitive and motor development. For example, cognitive development stimulated through indoor exercise, while motor development will be encouraged through free exercise. Cognitive and motor development are interconnected aspects. Through these examples, researchers created the Jump Count game through the abacus ladder media. This game aims to dissect cognitive and motor indicators in depth. This research uses the descriptive quantitative method. The results of the study based on the instrument filling data with a check indicator on the cognitive and motor development of children aged $5-6$ years; the data is presented in the form of a percentage. This research conducted in Raudatul Athfal (RA / Kindergarten) of Bunayya Yogyakarta with the research subjects of 14 children from the class of B2. The result showed that the Jump Count game could improve children's cognitive development by $34.1 \%$ and children's motor development by $36.7 \%$. It can concluded; this game can improve cognitive development, fine motor, and gross motor skills in children with an age range of $5-6$ years.
\end{abstract}

Keywords: Jump Count, Abacus Tangga, Cognitiv, Motor

\begin{abstract}
Abstrak
Anak usia dini adalah anak dengan rentang usia 0 sampai dengan 6 tahun yang harus diberi stimulasi untuk perkembangannya. Aspek perkembangan anak sesuai dengan permendikbud nomor 137 tahun 2014 ada 6 aspek yang meliputi aspek perkembangan fisik-motorik, nilai agama dan moral, bahasa, seni, motorik dan kognitif. Dalam penerapannya antara perkembangan satu dengan yang lainnya dapat distimulus secara bersamaan. Misalnya dalam aktivitas mewarnai maka aspek perkembangan yang terstimulus ada motorik halus dan seni. Dilapangan kadang kita jumpai pemisahan antara perkembangan kognitif dan motorik misalnya perkembangan kognitif selalu distimulasi di dalam ruangan (indoor) sedangkan motorik selalu distimulasi di luar ruangan (outdoor). Padahal perkembangan kognitif dan motorik saling berhubungan. Dari situlah peneliti menciptakan permainan Jump Count melalui media abacus tangga, dengan tujuan membedah secara mendalam indikator kognitif dan motorik apa saja yang tercapai dalam permainan ini. Penelitian ini menggunakan metode penelitian kuantitatif deskriptif, hasil
\end{abstract}


penelitian didasarkan pada olah data dari pengisian instrumen indikator ceklis perkembangan kognitif dan motorik anak usia 5-6 tahun dengan persentase. Penelitian ini dilakukan di RA Bunayya Yogyakarta dengan subjek penelitian 14 anak kelas B2. Hasil dari penelitian ini menunjukkan bahwa dalam permainan Jump Count dapat meningkatkan perkembangan kognitif anak sebesar 34,1 \% dan perkembangan motorik sebesar 36,7\%. Maka dapat disimpulkan bahwa permainan Jump Count melalui abacus tangga dapat meningkatkan perkembangan kognitif dan motorik halus maupun motorik kasar pada anak dengan rentang usia 5 - 6 tahun

\section{Kata Kunci: Jump Count, Abacus Tangga, Kognitif, Motorik}

\section{PENDAHULUAN}

Bagi anak usia dini bermain merupakan sebuah kebutuhan pokok. Menurut Muhammad Quraish ilmu itu bagaikan cahaya, bermain itu bagaikan belajar dan permainan itu bagaikan ilmu (Musbikin, 2010). Bermain juga sebagian dari menuntut ilmu, jadi biarkan anak-anak bermain. Karena itu adalah kebutuhannya, belajarnya dengan bermain. Dimana dengan bermain anak tersebut dapat mengembangkan berbagai aspek perkembangannya, belajar dengan alam, mengeksplorasi lingkungannya, mengkonstruk pengetahuannya, lebih lanjut ia bercerita bahwa zaman dahulu rasulullah juga mempercepat shalatnya, yaitu dua rakaat pada shalat dzuhur kemudian salah seorang makmum ada yang bertanya mengenai alasan mengapa Rasulullah mempercepat shalatnya. Rasulullah pun menjawab ia mempercepat dua raka'at shalat karena pada raka'at tersebut ia mendengar ada suara tangisan anak. Tidak hanya itu pernah suatu ketika Rasulullah memperlama sujudnya, sehingga makmum mengira terjadi sesuatu dengan Rasul. Kemudian Rasul bersabda yang isinya beliau mengungkapkan bahwa ia memperlama sujudnya karena cucunya (husain) sedang naik di punggungnya pada waktu Rasul bersujud. Dari uraian diatas jelas secara tersirat Rasul juga menyayangi anak - anak, bahkan dengan cucunya yaitu husain ketika Jabir Ra. ke rumah Rasul dan diajak makan tiba-tiba beliau melihat husain berlari bersama dengan teman - temannya. Melihat itu Rasul pun menghampiri mereka dan menembangkan tangan kemudian berlari kesana- kemari (Ulwan, 1999) .

Dari uraian panjang diatas menunjukkan bahwa betapa perhatiannya Rasul terhadap cucunya, beliau sangat menyayangi cucunya, membiarkan cucunya bermaian bahkan Rasul juga ikut bermain dengan cucunya. Sejatinya Islam mengajarkan kita untuk menyayangi anak, memberikan apa yang anak butuhkan termasuk kebutuhan untuk bermain, kebutuhan untuk bersosial dengan temantemannya, kebutuhan untuk dihargai, dan lain sebagainya. Hal ini juga dicantum dalam standar isi pusat kurikulum badan penelitian dan pengembangan departement pendidikan nasional pada tahun 2007 yang mengungkapkan bahwa upaya yang dilakukan untuk pengembangan harus dilakukan dengan cara bermain. Bermain adalah suatu aktivitas yang menyenangkan untuk anak usia dini, dengan bermaian anak dapat mengenal siapa dirinya, dengan siapa anak tersebut hidup, dal mengenal lingkungan tempat tinggalnya. Melalui bermain pula anak dapat berkreasi menemukan ide dan mengekpresikan perasaannya (Depdiknas, 2007) . Berbagai aspek perkembangan yang dapat dikembangkan antara lain perkembangan bahasa, emosi, kognitif, seni, agama dan motorik. Agar bermainnya terarah dan dapat mengembangkan berbagai aspek maka diperlukan 
permaianan yang didesign dan diciptakan untuk menstimulus berbagai aspek tersebut, syarat utamanya adalah harus menyenangkan. Jika anak senang dan bahagia maka neuron-neuron akan saling berhubungan dan dapat berinteraksi dengan sel yang bercabang, yang kemudian disebut dendrit, hal ini sangat baik bagi perkembangan otak anak (Porter \& Hernacki, 1999) .

Dalam penerapannya terkadang ada pemisahan untuk menstimulus perkembangan kognitif dengan motorik anak, misalnya untuk menstimulus perkembangan kognitif lebih banyak di ruang kelas indoor dengan mengerjakan lembar kerja atau majalah sedangkan untuk menstimulus motorik kasar lebih banyak di luar ruangan atau outdoor (Saripudin, 2019). Padahal sebenarnya motorik dan kognitif saling berhubungan. Hasil penelitian (Sasi, 2011, p . 51) menunjukkan bahwa senam irama dapat meningkatkan kognitif dan gera dasar anak, dalam hal ini yang dimaksud dengan gerak dasar adalah motorik kasar karena dalam senam irama tersebut anak bergerak melompat, berjinjit, berlari, memutar. Selain itu dalam penelitian (Yanti, Turdjai, \& Kurniah, 2017, p . 76) juga menunjukkan bahwa bermain sensorimotor efektif meningkatkan motorik dan kognitif anak. Dari uraian tersebut maka penulis ingin menyatukan pemisahan tersebut melalui sebuah permainan, kemudian peneliti akan menganalisis aspek perkembangan kognitif dan motorik apa saja yang ada didalam permainan Jump Count.

Jump Count adalah permainan yang didesign oleh peneliti untuk menstimulus aspek kognitif dan motorik anak secara bersamaan. Dalam permainan Jump Count ini menggunakan alat bantu permainan yaitu "abacus tangga". Abacus ada juga yang menyebutnya sempoa, sipoa atau sorokan merupakan alat hitung yang berasal dari jepang dan cina yang digunakan sebagai alat untuk berhitung (Pamilu, 2007). Dinamakan abacus tangga karena bentuknya menyerupai tangga. Abacus atau sempoa ini pada zaman dulu banyak dipakai orang-orang negara tiongkok sebagai media pembelajaran untuk mengenalkan penjumlahan, pengurangan, perkalian, dan pembagian. Pada masa itu abacus dinilai efektive sebagai media pembelajaran karena dapat mengkonkitkan pemahaman anak yang abstrak. Banyak sekali bentuk abacus ini, ada yang berbentuk persegi, persegi panjang, ada yang berbentuk seperti rak jemuran, tangga, dan lain-lain. Abacus tangga ini terbuat dari bahan kayu, triplek, kawat cat warna-warni, bentuknya memang sengaja dibuat seperti tangga dengan tujuan untuk memikat perhatian anak dan sebagai tinggi rendah jawaban. Peneliti memilih menggunakan media abacus tangga dikarenakan abacus ini sangat cocok untuk mengkonkritkan pemahaman anak tentang bilangan (Syifa \& Simatupang, 2015). Selain itu hasil penelitian (Kurniah, 2016) menunjukkan bahwa abacus dapat meningkatkan kemampuan berhitung anak. Dalam penggunaanya anak dapat menggeser manik-manik yang ada dalam abacus sesuai bilangan yang diberikan kemudian menambah atau mengurangkannya sesuai dengan pertanyaan.

Ditinjau dari segi bahasa Jump Count berasal dari bahasa inggris (Jump: melompat) dan (Count: berhitung, menghitung). Permainan Jump Count ini dapat dilakukan didalam secara indoor maupun outdoor dan dapat dilakukan secara individu maupun kelompok. Tata cara bermain ini adalah : *Sebelum permainan dimulai (1) Bunda guru menyiapkan potongan kertas kecil kira-kira ukuran setengah kertas HVS dan kotak kecil (2) Bunda guru menuliskan penjumlahan 
atau pengurangan bilangan sederhana, dan menyediakan tempat untuk anak membuat bentuk geometri (segitiga, persegi dan lingkaran) sesuai dengan jawaban bilangan tersebut (3) Setelah selesai bunda guru melintingnya kecil-kecil (4) Kemudian bunda guru memasukkan lintingan kertas tersebut kedalam kotak. *Saat permainan dimulai (1) Bunda guru menyiapkan anak-anak dengan nyanyian riang gembira atau bisa juga sesuai dengan tema pada hari itu (2) Setelah itu anak dipersilahkan mengambil lintingan yang berisi pertanyaan satu per satu (3) Kemudian anak diminta membuka dan menjawab dengan lompatan (4) Jika anak kesulitan menjawab atau jawabannya salah bunda guru mengarahkan anak untuk menghitung menggunakan abacus tangga dan menlihat bentuk geometri yang sama (5) Bunda guru memberikan arahan kepada anak bagaimana cara menggunakan abacus tangga (6) Setelah itu anak menggunakan abacus tangga untuk mencari jawaban (7) Setelah jawaban ditemukan anak menghampiri bunda guru sambil lari kecil-kecil lalu anak dipersilahkan menjawab pertanyaan dari bunda guru, menjawab dengan lompatan (8) Jika jawaban salah maka anak diminta kembali untuk menghitung dengan abacus tangga. *Setelah permainan (1) Bunda guru meminta anak untuk meluruskan kakinya, sambil menunggu temannya selesai menjawab (2) Bunda guru dan anak-anak menyanyikan lagu bebas tetapi harus menyenangkan (3) Bunda guru mereview beberapa pertanyaan yang ada dalam lintingan kertas dan mereview cara penggunaan abacus tangga. Contoh pertanyaan pada saat bunda guru mereview aktivitas dengan permainan Jump Count misalnya dengan pertanyaan : apakah hari ini anak-anak senang ? tadi kita bermain apa anak-anak ? ada yang tau $3+4$ berapa ? ada yang tau bentuk segitiga bagaimana ? kalau persegi bagaimana ? kalau lingkaran bagaimana ? ini namanya alat apa anak - anak (sambil menunjukkan abacus tangga)?

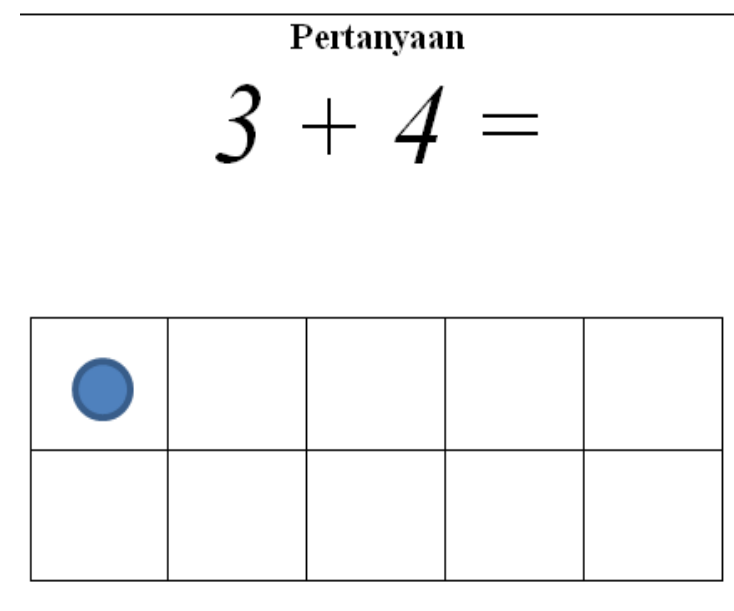

Gambar bentuk pertanyaa dari bunda guru

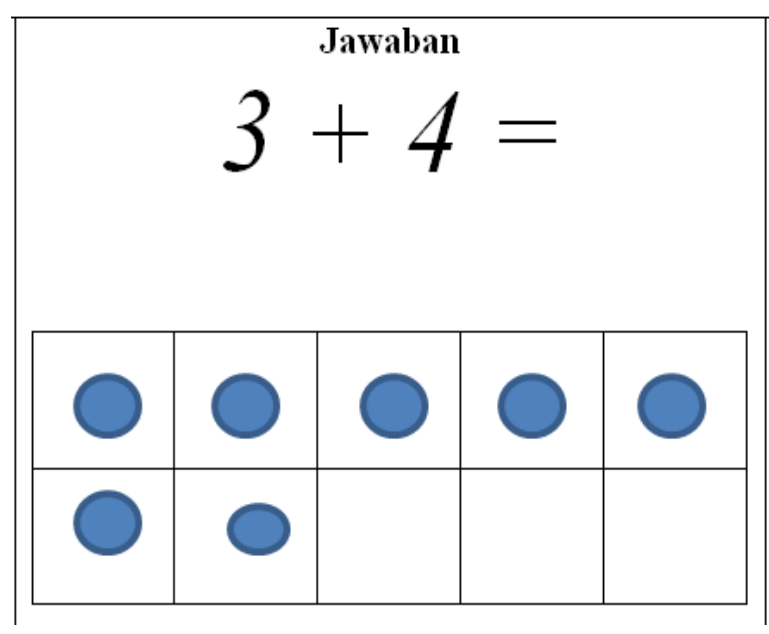

Gambar bentuk jawaban anak - anak

Berdasarkan wawancara dengan bunda guru manfaat permainan Jump Count ini adalah anak dapat belajar pentingnya bekerjasama (jika dilakukan secara kelompok), anak bisa lebih sigap dalam menghadapi permasalahan 
(mencari jawaban melalui abacus tangga), anak belajar untuk berani mengambil keputusan, anak belajar untuk tidak takut salah, memberikan rasa tanggung jawab yang tinggi karna anak diberi kepercayaan dari bunda guru menemukan jawaban secara mandiri, dapat menstimulus perkembangan kognitif anak, dapat menstimulus perkembangan motorik anak (motorik kasar maupun motorik halus. Permainan ini efektive dilakukan di pagi hari mengingat permainan ini membutuhkan tenaga dan pikiran cocok dilakukan pada saat otak fresh. Karna permainan ini menggunakan simbolik berhitung maka permainan Jump Count ini dirancang oleh peneliti untuk usia 5-6 tahun guna menyiapkan anak gemar berhitung di jenjang selanjutnya.

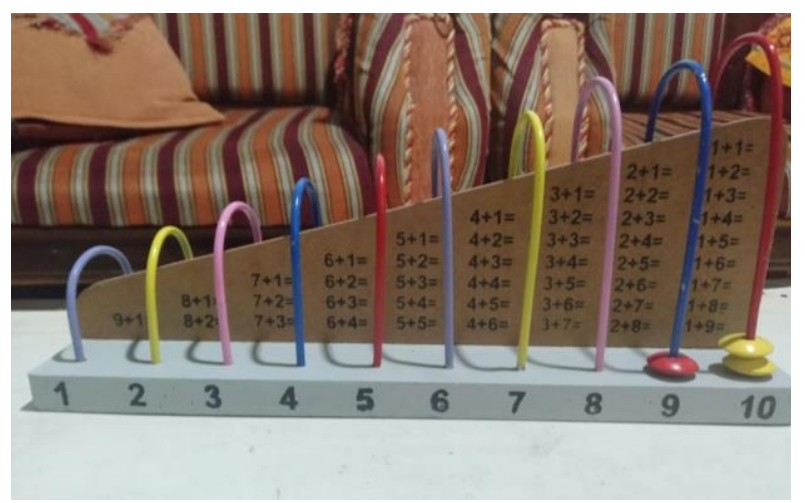

Gambar abacus tangga

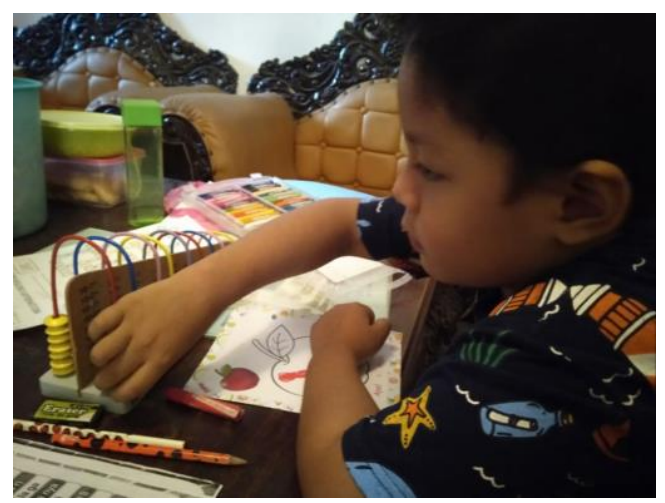

Gambar anak sedang menghitung dengan abacus tangga

Berdasarkan undang-undang no.137 tahun 2014 perkembangan anak terbagi menjadi 6 yaitu fisik-motorik, nilai agama dan moral, sosial emosiomal, bahasa, seni dan kognitif. Aspek perkembangan tersebut harus dikembangkan secara seimbang, namun dalam penelitian kali ini peneliti ingin membedah secara tuntas mengenai aspek perkembangan kognitif dan motorik yang terkandung di dalam permainan Jump Count.

Tabel indikator dan capaian perkembangan kognitif

\begin{tabular}{|c|c|}
\hline Indikator & Capaian perkembangan kognitif \\
\hline $\begin{array}{l}\text { Pemecahan } \\
\text { masalah }\end{array}$ & $\begin{array}{l}\text { Dapat memecahkan masalah sederhana } \\
\text { Dapat meneraapkan pengetahuan dan pengalaman } \\
\text { Menunjukkan sikap yang bersifat eksploratif dan } \\
\text { menyelidik } \\
\text { Menunjukkan sikap kreatif dalam menyelesaikan masalah } \\
\text { ide }\end{array}$ \\
\hline Berfikir logis & $\begin{array}{l}\text { Anak dapat berfikir tentang perbedaan, klasifikasi, pola } \\
\text { berinisiatif, berencana dan mengenal sebab-akibat }\end{array}$ \\
\hline $\begin{array}{l}\text { Berfikir } \\
\text { simbolik }\end{array}$ & $\begin{array}{l}\text { Anak dapat mengenal, menyebutkan dan menggunakan } \\
\text { konsep bilangan, mengenal huruf, serta mampu } \\
\text { mempresentasikan berbagai benda dan dapat } \\
\text { mengimajimasikan dalam bentuk gambar }\end{array}$ \\
\hline
\end{tabular}

Sumber permendikbud no 137 tahun 2012 tentang standar nasional PAUD 
Perkembangan kognitif merupakan perkembangan yang harus di kembangkan sejak dini karena akan menjadi pijakan awal anak untuk berfikir di jenjang yang lebih tinggi. Jean Piaget membagi perkembangan kognitif anak menjadi 4 tahap antara lain tahap sensorimotor pada usia 0 sampai 24 bulam, praoperasional pada usia 2 sampai 7 tahun, operasional konkrit pada usia 7 sampai 11 tahun dan formal operasional pada usia 1 tahun keatas. Berdasarkan tahap perkembangan kognitif tersebut makan anak dengan usia $5-6$ tahun memasuki pada tahan pra-operasional. Pada tahap ini anak belum siap untuk operasional ataupun manipulasi mental yang akan mengarah pada berfikir logis. Pada tahap ini pula anak berfikir secara simbolik, secara konkrit berlum dapat menggunkan pikiran logis. Selain itu anak usia 5-6 tahun sedang belajat tentang hubungan sebab-akibat, belajar memahmi angka melalui benda atau secara konkrit (Papalia, Old, \& Feldman, 2008). Dalam situasi yang mendesak anak dapat bertahan untuk mengerjakan sesuatu yang rumit dengan pengawasan orangtua, dapat memberi detail pada gambar-gambar, mulai belajar memahami angka secara konkrit (Meggitt, 2012, p . 146). Menurut (Menteri Pendidikan dan Kebudayaan Republik Indonesia, 2014) menyatakan bahwa perkembangan kognitif anak usia 5-6 tahun antara lain belajar memecahkan masalah, befikir logis dan berfikir simbolik. Berpijak dari teori Jean Piaget tentang perkembangan kognitif itulah peneliti menggunakan media abacus tangga untuk mengkonkritkan pemikiran anak, selain itu abacus tangga dapat menyimbolkan bilangan.

Tabel indikator dan capaian perkembangan motorik

Indikator perkembangan motorik

Motorik Kasar

Motorik Halus

\section{Capaian perkambangan usia}

Kemampuan menggerakkan tubuh secara

terkoordinasi, lentur, seimbang,lokomotor, nonlokomotor, lincah dan mengikuti aturan

Kemampuan dan kelenturan menggunakan jari

dan alat untuk mengeskplorasi dan

mengekspresikan diri dalam

berbagai bentuk

Sumber permendikbud no 137 tahun 2012 tentang standar nasional PAUD

Berdasarkan tabel perkembangan sesuai dengan (Menteri Pendidikan dan Kebudayaan Republik Indonesia, 2014) nomor 137 menyebutkan bahwa motorik terbagi menjadi dua indikator. Perkembangan motorik adalah perkembangan dengan mengendalikan gerakan jasmaniah malalui gerakan otot, pusat syaraf, aktivitas yang menggunakan koordinasi otot dan syarat otot, perkembangan motorik anak usia dini terbagi menjadi 2 yaitu motorik kasar dan motorik halus (Hurlock, 1978, p. 150). Motorik halus atau Fine Motor merupakan gerakan atau aktivitas yang menggunakan koordinasi otot halus pada otot kecil, karena otot kecil ini memerankan peran yang utama (Beaty, $2013 \mathrm{p}$. 37). Pada dasarnya motorik halus ini dapat menunjukkan kemauan dan kesempatan anak belajar misalnya dengan motorik halus menghubungkan titik-titik (dot connecting) kita dapat melihat seberapa besar kemauan anak tersebut untuk belajar dan mencoba (Soetjiningsih \& Ranuh, 2015, p. 31). Milestone perkembangan motorik halus usia 
5 - 6 tahun (1) menggambar persegi tanpa bantuan (2) dapat menangkap bola dengan kedua tangan (Needlman, 2004). Motorik kasar atau (Gross Motor) adalah aktivitas atau kegiatan yang menggunakan koordinasi otot besar contohnya melompat, berlari, jalan dengan seimbang, lokomotor dan nonlokomotor (Menteri Pendidikan dan Kebudayaan Republik Indonesia, 2014).

Berdasarkan paparan diatas, betapa pentingnya kita sebagai orang dewasa mendampingi perkembangan anak. Terlebih perkembang kognitif yang akan digunakan untuk landasan berfikir kelak ketika dewasa, dan motorik yang akan menyeimbangkan untuk berperilaku gesit. Dari permainan Jump Count melalui media abacus tangga ini peneliti optimis bahwa permainan ini dapat meningkatkan dan menstimulus perkembangan kognitif dan motorik secara bersamaan. Hasil penelitian (Khotimah, n.d.) menujukkan bahwa sempoa dapat meningkatkan kognitif anak usia 3 - 4 tahun dan hasil penelitian (Yani \& Indarto, 2017 , p. 2) yang menunjukkan bahwa permaina lompat tali efektiv untuk meningkatkan motorik kasar anak. Berdasarkan uraian panjang diatas maka peneliti ingin membedah secara mendalam perkembangan kogniti dan motorik apa saya yang tersimpan didlam permainan Jump Count dan berapa persen peran permainan Jump Count ini untuk menstimulus perkembangan kognitif dan motorik di RA Bunayya Yogyakarta.

\section{METODOLOGI}

Pada penelitian ini peneliti menggunakan metode penelitian kuantitatif dengan metode deskriptif. (Sugiyono, 2015, p. 264) dalam bukunya mengungkapkan bahwa metode kuantitatif tidak dipengaruhi oleh subjektive, artinya hasil penelitian didasarkan pada hasil perhitungan data / olah instrumen peneliti tentang analisis capaian kognitif dan motorik apa saja yang ada didalam permainan Jump Count melalui media abacus tangga di RA Bunayya Yogyakarta. Teknik pengumpulan data menggunakan dokumentasi dan pengisian instrumen penelitian. Sasaran penelitian ini adalah 14 anak yaitu kelas B2 RA Bunayya Yogyakarta. Untuk menganalisis capaian perkembangan apa yang masuk di dalam permainan Jump Count ini, peneliti menggunakan instrumen yang indikator ceklis yang di kembangkan dari Pusat Kurikulum DIKNAS tahun 2007 (Depdiknas, 2007) peneliti memilih berlandaskan pada Pusat Kurikulum DIKNAS tahun 2007 karena didalamnya terkandung indikator secara lengkap dan teperinci.

Tabel Capaian perkembangan kognitif usia $5-6$ tahun

\begin{tabular}{ll}
\hline Indikator & Capaian perkembangan kognitif usia 5-6 tahun \\
\hline $\begin{array}{l}\text { Klasifikasi } \\
\text { sederhana } \\
\text { Konsep sains }\end{array}$ & $\begin{array}{l}\text { Mengelompokkan benda } \\
\text { Menunjuk beda, hewan, tanaman } \\
\text { Menceritakan hasil eksperimen } \\
\text { Contoh balon yang ditiup kemudisn dilepas } \\
\end{array} \quad \begin{array}{l}\text { Posisi benda saat dimasukkan dalam air } \\
\text { Percobaan magnet }\end{array}$ \\
$\begin{array}{l}\text { Dapat membedakan rasa, bau dan suara } \\
\text { konsep } \\
\text { matematika }\end{array}$ & $\begin{array}{l}\text { Membilang 1-20 } \\
\text { Membilang dengan menunjuka 1-10 }\end{array}$ \\
\hline
\end{tabular}




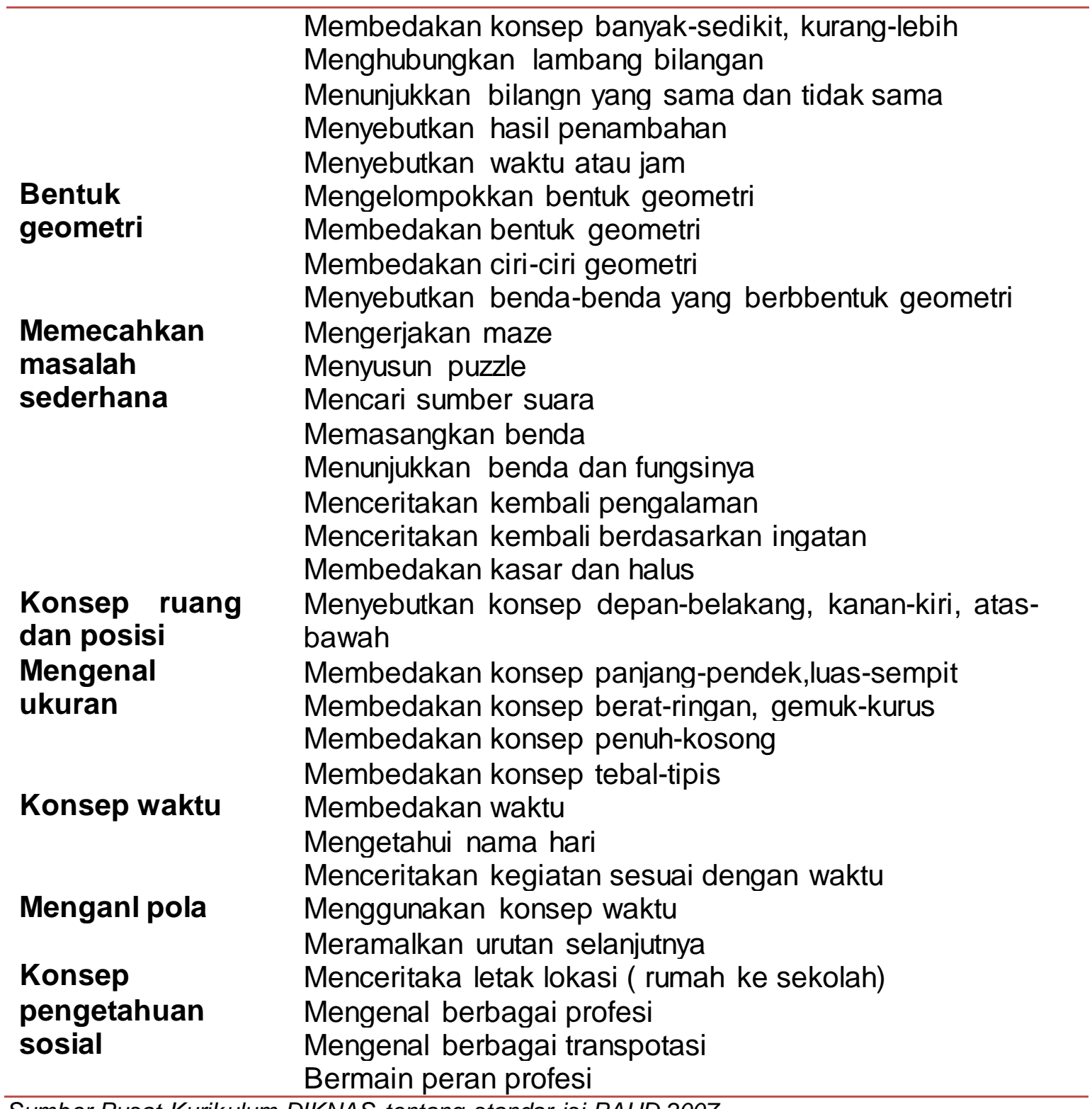

Sumber Pusat Kurikulum DIKNAS tentang standar isi PAUD 2007

Tabel Capaian perkembangan motorik usia $5-6$ tahun

\begin{tabular}{ll}
\hline Indikator & Capaian perkembangan kognitif usia $\mathbf{5 - 6}$ tahun \\
\hline Gerakan & Memutar dan mengayunkan lengan \\
ditempat & Meliukkan tubuh \\
& Membungkukkan bada \\
& Senam fantasi imitasi \\
Gerakan & Berjalan ke berbagai arah \\
berpindah & Melompat ke berbagai arah \\
tempat & Meloncat dengan ketinggian $30-40 \mathrm{~cm}$ \\
& Memanjat, bergelantung dan berayun \\
& Berdiri dengan tumit \\
& Berjalan sambil melompat \\
\hline
\end{tabular}




\begin{tabular}{ll}
\hline & Merayap dan merangkak dengan variasi \\
Koordinasi & Naik sepeda roda dua \\
tangan-mata & Mengurus diri sendiri \\
& Memegang pensil dengan benar \\
& Membuat berbagai bentuk dengan playdough \\
& Membuat garis lurus, datar, lengkung \\
& Melipat kertas 5-6 lipatan \\
& Menjahit bervriasi \\
& Mampu menggunting dengan berbagai media \\
& Mencocok bentuk \\
& Menyusun berbagai bentuk \\
& Membuat lingkaran dan persegi \\
& Meronce manik-manik \\
& Meronce dengan berbagai media \\
Gerakan tangan & Melanbungkan berbagai objek \\
& \\
(kelenturan) & Menangkap sesuatu objek \\
& Melempar objek dengan satu arah \\
& Menggulirkan bola menyusuri tanah \\
& Melempar objek kesasaran \\
& Bermain dengan simpai
\end{tabular}

Sumber Pusat Kurikulum DIKNAS tentang standar isi PAUD 2007

Teknik analisis data pada penelitian ini adalah menghitung data kuantitatif melalui olah persentase instrumen indikator ceklis, kemudian dilanjutkan dengan teknik deskriptif sesuai dengan hasil olah instrumen indikator ceklis. Hasil dari pengisian indikator ceklis kemudian di analisis teknik persentase menggunakan rumus (Purwanto, 2009, p. 102) :

$$
\begin{aligned}
& \mathrm{P}=\frac{F}{N} X 100 \% \text { Keterangan : } \\
& \mathrm{P}=\text { Persentase } \\
& \mathrm{F}=\text { Frekuensi (yang dicari) } \\
& \mathrm{N}=\text { Jumlah frekuensi (banyaknya individu) }
\end{aligned}
$$

Dari persentase tersebut dapat diketahui berapa besar permainan Jump Count dapat menstimulus aspek perkembangan kognitif dan motorik, selain itu dapat diketahui juga capaian apa saja yang terselip di dalam permainan tersebut.

\section{HASIL DAN PEMBAHASAN}

Permainan Jump Count adalah permainan yang dirancang oleh peneliti dengan tujuan untuk menstimulus aspek perkembangan kognitif dan motorik anak secara bersamaan dalam satu waktu. Permainan ini menggunakan media abacus tangga, untuk mengkonkritkan pemikiran anak. Mengingat pada usia $5-6$ tahun anak masih masuk pada tahap pra-operasional. Penelitian ini dilakukan di RA Bunayya Yogyakarta dengan 14 anak kelas B2. Dari pengisian instrumen indikator ceklis oleh bunda guru, kemudian peneliti olah diperoleh hasil sebagai berikut : 


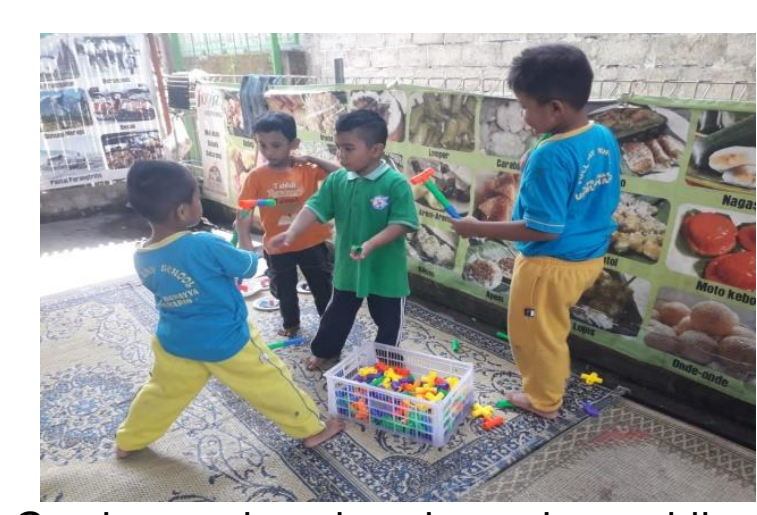

Gambar anak sedang bermain sambil menunggu temannya

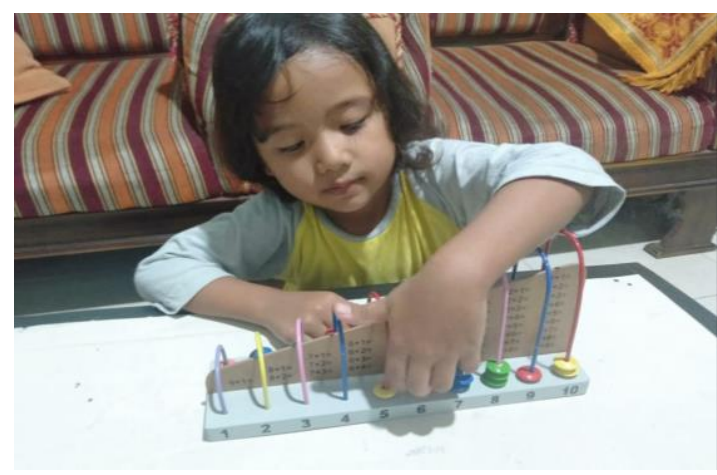

Gambar anak sedang menghitung dengan media abacus tangga

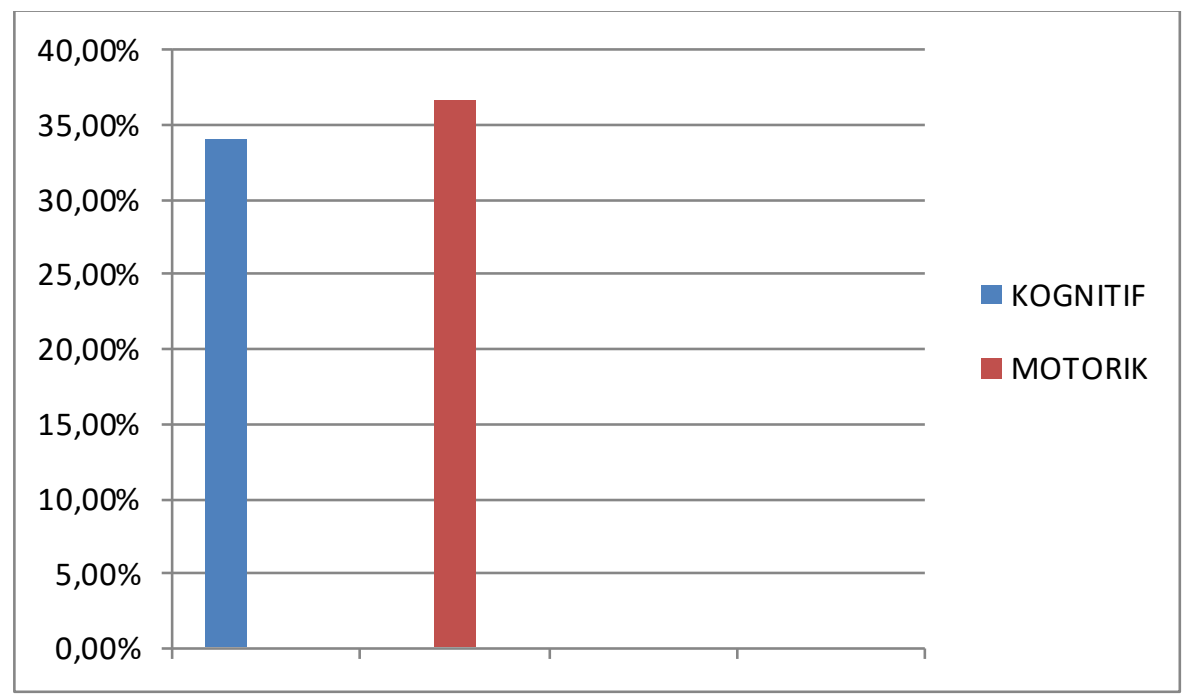

Diagram hasil olah data instrumen perkembangan kognitif dan motorik

Berdasarkan diagram tersebut terlihat jelas bahwa peran permainan Jump Count dalam mengembangkan perkembangan kognitif sebesar $34,1 \%$ dan perkembangan motorik sebesar $36,7 \%$. Angka tersebut menunjukkan bahwa Jump Count dapat mengembangkan perkembangan kognitif dan motorik secara bersamaan akan tetapi kurang maksimal. Menurut Amirono dan Daryanto skor di bawah 60\% masuk ke dalam kategori kurang maksimal (Amirono \& Daryanto, 2016). Pada perkembangan kognitif capaian perkembangan yang terceklis ada 14 poin ceklis dari 41 poin ceklis. Perkembangan kognitif dalam permainan ini meliputi (1) Mengelompokkan benda dengan berbagai cara, pada capaian ini anak dapat mengelompokkan dan membuat bentuk geometri yaitu setiga, persegi dan lingkaran. Secara acak anak memperoleh salah satu dari 3 bentuk geometri tersebut. (2) Menunjukkan benda, hewan dll yang sesuai dengan ciri tertentu, pada capaian ini anak dapat menunjukkan benda yang berbentuk sama dengan bentuk geometri yang anak dapatkan. (3) membilang angka 1-20, jelas pada capaian ini anak membilang sesuai dengan jawaban dari pertanyaan yang didapat. (4) Membilang dengan menunjuk 1-10, pada capaian ini anak dapat $\underline{\text { menjawab pertanyaan berkaitan dengan bilangan. (5) Menunjukkan urutan 1-10, }}$ 
pada capaian ini anak dapat menunjuk urutan 1-10 melalui bentuk geometri yang telah anak kerjakan. (6) Memasang lambang bilangan dengan benda sampai 10, pada capaian ini anak dapat memasang lambang bilangan di bawah bentuk geometri. (7) Menunjukkan jumlah sama dan tidak sama, jelas pada capaian ini anak menjawab tiga pertanyaan yang jawabannya berbeda jadi secara tersirat anak dapat menunjukkan hasil yang berbeda. (8) Menyebutkan hasil penambahan, jelas pada capaian ini anak akan diminta untuk mencari jawaban dari pertanyaan dari bunda guru. Jika anak kesulitan maka akan menggunakan bantuan medi abacus tangga. (9) Mengelompokkan bentuk geometri, pada capaian ini anak dapat mengelompokkan bentuk geometri mana yang sesuai dengan permintaan bunda guru atau bukan. (10) Membedakan bentuk geometri, jelas capaian ini tercapai karena ada pertanyaan yang berkaitan dengan bentuk geometri tersebut. (11) Membedakan ciri-ciri geometri, pada capaian ini jika anak berhasil menjawab berarti anak sudah mengetahui ciri geometri. Artinya capaian ini terpenuhi. (12) Menyebutkan benda-benda yang berbentuk geometri, pada capaian ini setelah anak melalukan lompatan sesuati dengan jawaban numerik. Maka bunda guru akan memberi pertanyaan terkait contoh benda apa yang bentuknya sama dengan bentuk geometri yang brusan dibuat. (13) Menceritakan kembali sesuatu berdasarkan ingatannya, capaian ini terjadi pada saat memasuki recalling, bunda guru me-recall kegiatan hari tersebut dengan pertanyaan. Hari ini kita belajar apa anak-anak? Siapa tadi yang membuat bentuk geometri segitiga ? Siapa tadi yang membuat bentuk geometri persegi ? Siapa tadi yang membuat bentuk geometri lingkaran ? tadi anak-anak melompat berapa kali ? bagaimana perasaan anak-anak? Senang ? bahagia ? (14) Memperkirakan urutan selanjutnya, indikator ini terjadi pada saat anak menghitung jawaban dari bunda guru.

Pada permainan Jump Count ini menggunakan media abacus tangga, banyak sekali manfaatnya terutama untuk mengembangkan kognitif anak, menjadikan anak gemar berhitung, abacus dicat warna-warni untuk menarik perhatian anak dan menyanangkan. Menurut Montessori anak dengan mudah belajar dengan simbol, dalam hal ini abacus tanggalah yang menyibolkan, mengkonkritkan bilang yang abstrak dalam pikiran anak (Erawati, 2010, p. 63). Kemudian Burner mengungkapkan tahapan membilang pada anak ada 3 antara laian manipulasi benda konkrit, melalui gambar dan dan melaui simbol atau lambang (Sulistiati \& Nunik, 2014).

Pada aspek perkembangan motorik indikator yang terceklis ada 11 poin indikator dari 30 poin indikator motorik kasar dan motorik halus antara lain (1) Memutar dan mengayunkan lengan, pada permainan Jump Count ini ketika anak melompat otomatis anak mengayunkan lengannya artinya indikator ini masuk dalam permainan Jump Count. (2) Meliukkan tubuh, sebelum anak melompat anak akan diajak pemanasan dahulu oleh bunda guru dengan meliukkan tubuh ke depan dan belakang. Pemanasan ini bertujuan agak pada saat anak melompat otot-ototnya tidak kaku. (3) Membungkukkan badan, dalam hal ini membungkukkan badan masih masuk dalam rangkaian pemanasan. (4) Berjalan ke berbagai arah, pada saat anak dipanggil oleh bunda guru anak otomatis berjalan kearah bunda guru untuk mengambil atau memilih lintingan kertas yang berisi pertanyaan. (5) Melompat ke berbagai arah, indikator ini dilakukan pada saat anak melompat menjawab pertanyaan dari bunda guru anak melompat 
sesuai dengan hitungan jawaban. Karena jawaban lebih dari 3 maka anak melompat sesuai dengan lompatan mereka, lompatan pertama ada yang menghadap utara, lomapata kedua ada yang menghadap timur, lompatan ketiga ada yang menghadap selatan dll. (6) Melompat dengan ketinggian $30-40 \mathrm{~cm}$, pada indikator ini rata-rata anak melompat diatas $30 \mathrm{~cm}$ mengingat usia anak tersebut sudah 5 tahun ke atas jadi lompatan meraka sudah memenuhi target ini. (7) Berdiri dengan tumit, berdiri dengan satu kaki, pada saat anak melompat lebih dari 3 lompatan. Lompatan ke dua dan ke tiga dan seterusnya terkadang anak menggunakan tumit sebagai tumpuan. (8) Berlari sambil melompat, pada permainan ini anak menghampiri bunda guru dengan berlari dan kemudian melanjutkan dengan melompat sesuai jawaban. (9) Memegang pensil dengan benar, pada saat anak menulis jawaban angka maupun bentuk geometri dari bunda guru tentu saja anak harus bisa menggunakan pensil dengan benar. Disini anak berlatih untuk memegang pensil diantara ibu hari dan dua jari dengan benar. (10) Meniru membuat garis tegak, datar miring, pada permainan ini soal petanyaan dari bunda guru berhubungan dengan geometri, jadi anak sebisa mungkin dapat membuat garis tegak, datar, miring sesuai dengan bentuk geometri yang mereka dapatkan. (11) Melambungkan berbagai objek, pada permainan ini anak setalah anak menyelesaikan tugasnya anak dapat bermain bebas, bunda guru menyiapkan bola untuk bermain lempar tangkap bola. Berdasarkan hasil temuan yang telah dipaparkan tersebut maka dalam permainan Jump Count melalui media abacus tangga dapat menstimulus perkembangan kognitif dan motorik kasar maupun halus secara bersamaan. Dalam menstimulus perkembangan kognitif dan motorik permainan Jump Count ini berperan sebesar $34,1 \%$ untuk menstimulus perkembangan kognitif dan 36,7 \% untuk menstimulus perkembangan motorik, angka tersebut mempunyai makna bahwa dalam mengembangkan perkembangan kognitif dan motorik anak dengan permainan ini kurang optimal karena hasil persentase di bawah 60\%. Artinya permainan Jump Count dapat diterapkan di sekolah untuk meningkatkan perkembangan kognitif dan motorik anak namun bunda guru diharapkan menambahkan beberapa aktivitas lagi untuk mengoptimalkan perkembangan anak. Hal ini di dukung oleh penelitian Amalia yang menyatakan bahwa permainan Jump Numbers dapat berpengaruh terhadap perkembangan kognitif anak antara lain dalam mengenal lambang bilangan, angka pada anak usia 5 - 6 tahun (Amalia, 2016). Selain itu hasil penelitian Sri Wahyuni menunjukkan bahwa pengaruh permainan Jump Numbers terhadap kemampuan mengenal konsep bilangan anak pada rentang usia 4 - 5 tahun sebesar 50,40 \% (Wahyuni, Zulkifli, \& Hukmi, n.d.). Hal yang sama juga diterapkan oleh Maya Putri Yani dengan permainan tradisional lompat tali, peran permainan lompat tali untuk menstimulus perkembangan motorik kasar pada anak usia 5 - 6 tahun sebesar 53,69 \% (Wahyuni et al., n.d.). Semua temuan penelitian yang dipaparkan diatas manunjukkan bahwa semua permainan dapat meningkatkan perkembangan anak, karena pada dasarnya anak belajar dengan bermain. Dalam Permainan Jumpa Count melalui abacus tangga dapat menstimulus perkembangan kognitif dan motorik secara bersamaan.

\section{SIMPULAN}

Perkembangan Kognitif merupakan perkembangan yang urgen untuk dikembangkan sebab perkembangan kognitif berhubungan dengan pola pikir, 
kecerdasan, dan pengetahuan. Perkembangan motorik anak menunjang perkembangan kognitifnya, jika anak dalam keadaan sehat dan bugar maka anak akan cepat menangkap informasi pengetahuan. Berdasarkan hasil dan pembahasan diatas dapat disimpulkan bahwa permainan Jump Count melalui abacus tangga dapat meningkatkan perkembangan kognitif dan motorik halus maupun motorik kasar secara bersamaan pada anak dengan rentang usia $5-6$ tahun di RA Bunayya Yogyakarta. Dalam menstimulus perkembangan kognitif dan motorik permainan Jump Count ini berperan sebesar 34,1\% untuk menstimulus perkembangan kognitif dan 36,7 \% untuk menstimulus perkembangan motorik. Angka tersebut masuk dalam katagori kurang optimal, hal ini dapat menjadi bahan referensi penelitian lanjutan bagi civitas akademik yang ingin melalukan penelitian selanjutnya untuk menambah aktivitas pada permainan Jump Count melalui abacus tangga agar didapatkan hasil yang optimal.

\section{DAFTAR PUSTAKA}

Amalia, M. (2016). Pengaruh Aktivitas Bermain Jump Numbers Terhadap Perkembangan Kemampuan Mengenal Lambang Bilangan Anak Usia 5-6 Tahun Di TK Ramadhan Bandar Lampung Tahun Pelajaran 2015/2016. 2016.

Amirono, M. T., \& Daryanto. (2016). Evaluasi Dan Penilaian Pembelajaran Kurikulum 2013. Yogyakarta: Gava Media.

Beaty, J. J. (2013). Observasi Perkembangan Anak Usia Dini (7th ed.; A. K. Anwar, ed.). Jakarta: KENCANA.

Depdiknas. (2007). Standar isi pendidikan anak usia dini. 1-62.

Erawati, E. (2010). Upaya Peningkatan Kemampuan Mengenal Bilangan Anak.

Hurlock, E. B. (1978). Perkembangan Anak. Jakarta: Erlangga.

Khotimah, N. (n.d.). Meningkatkan Kemampuan Kognitif Melalui Permainan Abacus Angka Usia 3-4 Tahun. 1-6.

Kurniah, N. (2016). Peningkatan Kemampuan Berhitung Anak Melalui Kegiatan Bermain Sempoa. 1(2), 72-77.

Meggitt, C. (2012). Memahami Perkembangan Anak (13th ed.; T. Index, ed.). Jakarta Barat.

Menteri Pendidikan dan Kebudayaan Republik Indonesia. (2014). Permendikbud No. 137 Tahun 2014 tentang Standar Nasional PAUD.

Musbikin, I. (2010). Buku Pintar PAUD (Dalam Perspektif Islami) (1st ed.; Sudjatna, ed.). Jogjakarta: Laksana.

Needlman. (2004). Growth and Development.

Pamilu, A. (2007). Mengembangkan Kreativitas \& Kecerdasan Anak. Jakarta: Citra Media.

Papalia, D. E., Old, S. W., \& Feldman, R. D. (2008). Human Development (9th ed.). Jakarta: Kencana Prenada Media Group.

Porter, B. De, \& Hernacki, M. (1999). Quantum Learning (5th ed.; S. Meutia, ed.). New York: Kaifa.

Purwanto, N. (2009). Prinsip-prinsip dan teknik evaluasi pengajaran. Bandung: Remaja Rosdakarya.

Saripudin, A. (2019). Analisis Tumbuh Kembang Anak Ditinjau Dari Aspek Perkembangan Motorik kasar Anak Usia Dini. Equalita, 1(1). 
Sasi, D. N. (2011). Meningkatkan Kemampuan Gerak Dasar Dan Kognitif Anak Melalui Senam Irama. (1), 46-52.

Soetjiningsih, \& Ranuh, G. (2015). Tumbuh Kembang Anak (2nd ed.; J. Suyono, ed.). Jakarta: Penerbit Buku Kedokteran EGC.

Sugiyono. (2015). Cara Mudah Menyusun Skripsi, Tesis, dan Disertasi (3rd ed.; A. Nuryanto, ed.). Bandung: Alfabeta.

Sulistiati, \& Nunik. (2014). Pembelajaran Matematika Terpadu Untuk Anak. Unesa.

Syifa, F. M., \& Simatupang, N. D. (2015). Penggunaan sempoa dalam pengembangan kemampuan berhitung permulaan anak.

Ulwan, A. N. (1999). Pendidikan Anak Dalam Islam. Jakarta: Pustaka Amani.

Wahyuni, S., Zulkifli, N., \& Hukmi, S. (n.d.). The Influence Of Playing Jump Numbers To Know Concept Number Ability Of Child Age 4-5 Years In Tk Agape Tampan Sub Distric Pekanbaru City Kemampuan Mengenal Konsep Bilangan Anak Usia 4-5 Tahun Di Tk Agape. 1-15.

Yani, M. P., \& Indarto, W. (2017). The Effect Of Jumping String Traditional Game Toward The Crude Motor Ability Of 5-6 Years Old Childrend In Kasih Ibu Kindergarten School Kasikan Village Upper Course Terhadap Kemampuan Motorik Kasar Pada Anak Usia 5-6 Tahun Di Tk Kasih Ibu Desa. 1-15.

Yanti, septi damai, Turdjai, \& Kurniah, N. (2017). Penerapan Metode Bermain Sensorimotor Untuk Meningkatkan Kognitif Dan Motorik Halus Anak (Studi Pada Anak Kelompok A1 Paud Negeri Pembina 1 Kota Bengkulu) 1. 7(2), $1-7$. 